\title{
Possible involvement of regulatory $T$ cells in tumor onset and progression in primary breast cancer
}

\author{
Masahiro Ohara $\cdot$ Yoshiyuki Yamaguchi • \\ Kazuo Matsuura $\cdot$ Shigeru Murakami · \\ Koji Arihiro $\cdot$ Morihito Okada
}

Received: 9 November 2007 / Accepted: 21 July 2008 / Published online: 7 August 2008

(C) The Author(s) 2008. This article is published with open access at Springerlink.com

\begin{abstract}
Background The FOXP 3 mRNA expression and the other regulatory $\mathrm{T}$ cell-related molecules were investigated and compared with clinicopathological parameters in human primary breast cancer.

Method This study included 136 breast cancer patients operated in our department from 2003 to 2006. Total RNA was extracted from frozen normal breast and breast cancer tissues, and the expression of FOXP3, IL-10,TGF $\beta 1$ and CCL22 mRNA was evaluated using quantitative real-time RT-PCR.

Result FOXP3, IL-10, TGF 1 and CCL22 mRNA expressions were significantly higher in cancer tissue than in normal tissue, not only at pT1, 2, and 3 stages but also at the DCIS stage. There were positive correlations between FOXP 3 and $I L-10, F O X P 3$ and TGF $\beta 1$, as well as FOXP3 and $C C L 22$ mRNA expressions, respectively. FOXP3 and $I L-10$ mRNA expressions were significantly upregulated in PgR-negative or HER2-positive tumors.
\end{abstract}

M. Ohara · Y. Yamaguchi · K. Matsuura · S. Murakami · M. Okada Department of Surgical Oncology,

Research Institute for Radiation Biology and Medicine,

Hiroshima University, Kasumi 1-2-3,

Minami-ku, Hiroshima 734-8553, Japan

e-mail: oharamas@hotmail.com

\section{K. Arihiro}

Department of Anatomical Pathology,

Hiroshima University, Kasumi 1-2-3,

Minami-ku, Hiroshima 734-8553, Japan

Present Address:

Y. Yamaguchi $(\square)$

Department of Clinical Oncology, Kawasaki Medical School,

Matsushima 577, Kurashiki, Okayama 701-0192, Japan

e-mail:shogo@med.kawasaki-m.ac.jp
Conclusion These results suggest that regulatory $\mathrm{T}$ cells are involved in tumor onset and progression in human primary breast cancer, possibly contributing to poor prognosis of patients with breast cancer.

Keywords FOXP3 - CCL22 - IL-10 - TGF $\beta 1$.

Regulatory $\mathrm{T}$ cells

\section{Introduction}

Regulatory $\mathrm{T}$ (Treg) cells have been highlighted in tumor immunology [1,2]. Although Treg cells protect hosts in vivo against the development of autoimmunity, they also suppress the reaction of lymphocytes to tumor antigens in some malignant neoplasms [3]. This suppression helps the neoplasms to escape from the host immune system [4]. Therefore, to explore the existence of Treg cells in cancer patients and the involvement of Treg cells in tumor onset and progression is an important issue to be clarified. It has been reported that Treg cells are increased in peripheral blood in patients with non-small cell lung cancer [5, 6] and gastrointestinal malignancies [7], in sentinel lymph nodes in breast cancer [8], and in tumor nodules in head and neck [9], prostate [10], and breast [11, 12] cancers. Although these reports have suggested Treg cell involvement in tumor progression, it still requires more clinical samples to define Treg cell significance in tumor onset and progression of breast cancer.

Treg cells are originally characterized by the co-expression of CD4 and CD25 molecules [13, 14]. Treg cell activity is known to be closely associated with the expression of forkhead/winged helix transcription factor, Foxp3. Although Foxp3 is not induced upon activation of CD25 $\mathrm{T}$ cells, naive $\mathrm{CD} 4^{+} \mathrm{CD} 25^{-} \mathrm{T}$ cells transform into Treg cells 
when Foxp3 is introduced via retrovirus or enforced transgene expression $[15,16]$. Recently, $\mathrm{CD} 4^{+} \mathrm{CD} 25^{-} \mathrm{T}$ cells were induced to express FOXP3 and achieve regulatory function by stimulation through the T-cell receptor (TCR) in humans [17] and transforming growth factor- $\beta$ (TGF $\beta$ ) in mice [18]. From these findings, FOXP3 can be considered to be a critical regulator of Treg cell development and function in mice and humans. Although the precise mechanisms of immunosuppression by Treg cells remain to be determined, Treg cells can inhibit immune cell functions either directly through cell-to-cell contact or indirectly through the secretion of anti-inflammatory mediators such as IL-10 and TGF $\beta 1$. The antigens recognized by Treg cells appear to be self, tissue-specific antigens [19]. More recently, the molecular mechanisms of Treg cell migration have been precisely demonstrated: Treg cells express chemokine receptor CCR4 and show demonstrable chemotactic responses to the CCR4 ligands CCL22 and CCL17 [20].

Based on the above findings, we studied Treg cell involvement in the onset and progression of 136 human breast cancer samples by using RT-PCR for FOXP $3, I L-10$, $T G F \beta 1$ and CCL22 mRNA expressions. We analyzed the relationship between these molecular expressions and known clinicopathological parameters of prognosis such as the size of the primary tumor, histologic tumor grade, lymph node status, estrogen (ER) and progesterone receptor $(\mathrm{PgR})$ expression, HER-2/neu expression, and lymphatic and vascular invasion.

\section{Materials and methods}

Patients enrolled

Adult female patients with primary breast cancer who underwent breast surgery at the Hiroshima University Hospital between 2003 and 2006 were enrolled in this study. The study was approved by the institutional review board of Hiroshima University Hospital, and written informed consent was obtained from all enrolled patients. Normal breast tissues were taken from a site distant from the tumorous lesion $(n=11)$.

\section{RT-PCR}

Total RNA was extracted from stored tumor tissues with an RNeasy Mini Kit (QIAGEN, Hilden, Germany). DNase treatment was performed with the RNase-Free DNase Set (QIAGEN) to avoid amplification of contaminating genomic DNA. The quality and quantity of the obtained total RNA were determined by absorbance at 260 and $280 \mathrm{~nm}$ and were adjusted to a concentration of $0.10 \mu \mathrm{g} / \mu \mathrm{L}$. In addition, the integrity of RNA in each preparation was tested by RT-PCR of glyceraldehyde-3-phosphate dehydrogenase (GAPDH). The prepared total RNA served as the template for first-strand cyclic DNA (cDNA) synthesis using Ready-To-Go ${ }^{\mathrm{TM}}$ You-Prime-First-Strand Beads (Amersham Pharmacia Biotech Inc., Piscataway, NJ, USA) with $0.5 \mu \mathrm{g}$ of Oligo (dT) 15 primer (Novagen, Darmstadt, Germany) according to the manufacturer's instructions. Each cDNA product was diluted tenfold with RNase-free water to avoid inhibition of the PCR reaction by reagents used in RNA extraction or reverse transcription. For relative quantification by PCR, each cDNA product was analyzed at a final $\mathrm{Mg}^{2+}$ concentration of $3 \mathrm{mM}$ in a LightCycler with software (version 3.5; Roche Molecular, Mannheim, Germany) by using the FastStart DNA Master SYBR Green I Kit (Roche Diagnostics, Mannheim, Germany). For each primer pair, a standard curve was developed. The PCR condition was $95^{\circ} \mathrm{C}$ for $10 \mathrm{~min}$ for the initial denaturation, followed by 35 cycles of 1 second at $95^{\circ} \mathrm{C}, 10 \mathrm{~s}$ at $60^{\circ} \mathrm{C}$, and $10 \mathrm{~s}$ at $72^{\circ} \mathrm{C}$, followed by a melting program (at $60-95^{\circ} \mathrm{C}$ ) to check the proper melting temperature of the product. Annealing temperatures and elongation times were optimized for primer generation and exclusion of artifacts. Primers for FoxP3, IL-10, TGF $\beta 1$, CCL22 and GAPDH were from Search-LC GmbH (Heidelberg, Germany).

All clinical samples were amplified by PCR, and the quality of amplification was checked with Light Cycler $\mathrm{R}$ software (version 3.5; Idaho Technology Inc., Salt Lake City, UT, USA) by calculating the ratio of the crossing point (threshold cycle number for the beginning of the exponential phase) and the logarithm concentration of the amplified copy number for each standard sample [21].

\section{Statistical analysis}

The Mann-Whitney $U$ test and Kruskal-Wallis test were used when testing categorical or continuous categorical data against categories. Spearman's rank correlation and simple regression analysis were used to identify associations in the expression of each parameter with StatView software (version 5 for Windows; Abacus Concepts, Inc., London, UK). $P$ values $<0.05$ were considered significant.

\section{Results}

Patient and tumor characteristics

Background data of patients with regard to age, histologic type of tumor, pathologic (p)TNM classification, ER, PgR, HER2, and lymphatic and vascular invasion status are summarized in Table 1. The enrolled patients were $58.1 \pm 13.0$ years old (mean \pm standard deviation; range 
Table 1 Patients and tumor charateristics

\begin{tabular}{|c|c|c|}
\hline & $\begin{array}{l}\text { Total } \\
(n=136)\end{array}$ & $\%$ \\
\hline \multicolumn{3}{|l|}{ Age (year) } \\
\hline Mean \pm SD & $58.1 \pm 13.0$ & \\
\hline Range & $33-88$ & \\
\hline \multicolumn{3}{|l|}{ pT category } \\
\hline pTis (DCIS) & 12 & \\
\hline pT1 & 84 & 62 \\
\hline pT2 pT3 & 40 & 29 \\
\hline \multicolumn{3}{|l|}{ pN category } \\
\hline pN0 & 94 & 69 \\
\hline $\mathrm{pN} 1 \mathrm{pN} 2 \mathrm{pN} 3$ & 37 & 27 \\
\hline $\mathrm{pNX}$ & 5 & 4 \\
\hline \multicolumn{3}{|l|}{ Tumor histologic type } \\
\hline Noninvasive ductal carcinoma & 12 & \\
\hline Invasive ductal carcinoma & 107 & 79 \\
\hline Special types & 17 & 13 \\
\hline \multicolumn{3}{|l|}{ Tumor grade (SBR) } \\
\hline Grade 1 & 31 & 23 \\
\hline Grade 2 & 51 & 38 \\
\hline Grade 3 & 53 & 39 \\
\hline Unknown & 2 & \\
\hline \multicolumn{3}{|l|}{ Lymphatic invasion score } \\
\hline 0 & 87 & 64 \\
\hline 1.2 .3 & 49 & 36 \\
\hline \multicolumn{3}{|l|}{ Vascular invasion score } \\
\hline 0 & 136 & 100 \\
\hline 1.2 .3 & 0 & \\
\hline \multicolumn{3}{|l|}{ Hormone receptor status } \\
\hline ER-positive & 120 & 88 \\
\hline ER-negative & 16 & 12 \\
\hline PgR-positive & 102 & 75 \\
\hline PgR-negative & 34 & 25 \\
\hline \multicolumn{3}{|l|}{ HER2 status } \\
\hline Negative & 106 & 78 \\
\hline Positive & 28 & 21 \\
\hline Unknown & 2 & 1 \\
\hline
\end{tabular}

$\overline{S D \text { standard deviation, } E R \text { estrogen receptor, } P g R \text { progesterone recep- }}$ tor, SBR Scarff-Bloom-Richardson

33-88 years). Of the 136 patients enrolled, 12 had pTis status, 84 had pT1 status, and 40 patients pT2 or pT3 status. Ninety-four patients had pN0 status, and 37 had pN1, N2, and N3 status. Seventy-nine percent of the tumors were determined to be invasive ductal carcinomas according to standard histopathology (hemtoxylin and eosin staining). Greater than $70 \%$ of the tumors expressed estrogen $(88 \%)$ or progesterone $(75 \%)$ receptors. Twenty-one percent of the patients had positive HER2 status and $78 \%$ of the patients negative HER2 status according to HercepTest-immunostaining and fluorescence in situ hybridization (FISH). One-third of the patients had Scarff-Bloom-Richardson grades 1,2 , or 3 . Approximately two-thirds of the patients showed a lymphatic invasion score of 0 , and none of the patients had vascular invasion.

\section{FOXP3 and $I L-10$ mRNA expressions}

We used quantitative RT-PCR to analyze FOXP3 and $I L-10$ mRNA expressions in breast cancer tissue and compared expression levels against each clinicopathological factor (Table 2). There was no correlation between FOXP3 mRNA expression and $\mathrm{pT}$ category (data not shown). However, FOXP3 mRNA expression in cancer tissue was significantly upregulated when compared with normal breast tissue expression $(P<0.01)$, even at the ductal carcinoma in situ (DCIS) stage $(P<0.01)$ (Fig. 1a). Similar results were obtained in $I L-10$ mRNA expression (Fig. 1b). The upregulation of FOXP3 and $I L-10$ mRNA expressions persisted at the pT1 and pT2, 3 stages $(P<0.01)$ (Fig. 1a, b), showing the expression levels of $7.4 \pm 10.9,170.5 \pm 207.9,205.1 \pm 184.1,165.7 \pm 200.9$ and $170.3 \pm 231$ copies in FOXP3 mRNA, and $61.73 \pm 118.4$,

Table 2 Relationship between FOXP3, IL-10, TGF and clinicopathological factors (only correlative parameters and their values)

\begin{tabular}{|c|c|c|c|}
\hline & $n(\%)$ & Mean \pm SD & $P$ value \\
\hline \multicolumn{4}{|l|}{$F O X P 3$} \\
\hline \multicolumn{4}{|c|}{ Tumor grade (SBR) } \\
\hline Grade 1 & $31(22 \%)$ & $108.8 \pm 129.6$ & \\
\hline Grade 2 & $51(38 \%)$ & $152.2 \pm 162.3$ & \\
\hline Grade 3 & $53(39 \%)$ & $222.9 \pm 267.6$ & 0.0981 \\
\hline \multicolumn{4}{|c|}{ Hormone receptor status } \\
\hline PgR-positive & $102(75 \%)$ & $144.2 \pm 180.8$ & \\
\hline PgR-negative & $34(25 \%)$ & $249.5 \pm 260.9$ & 0.0075 \\
\hline \multicolumn{4}{|l|}{ HER2 status } \\
\hline Negative & $106(79 \%)$ & $150.4 \pm 187.3$ & \\
\hline Positive & $28(21 \%)$ & $255.0 \pm 234.6$ & 0.007 \\
\hline \multicolumn{4}{|l|}{$I L-10$} \\
\hline \multicolumn{4}{|l|}{ pN category } \\
\hline pNO & $94(69 \%)$ & $97.2 \pm 146.5$ & \\
\hline $\mathrm{pN} 1 \mathrm{pN} 2 \mathrm{pN} 3$ & $37(27 \%)$ & $122.9 \pm 130.2$ & 0.067 \\
\hline \multicolumn{4}{|c|}{ Hormone receptor status } \\
\hline PgR-positive & $102(75 \%)$ & $91.1 \pm 121.9$ & \\
\hline PgR-negative & $34(25 \%)$ & $138.4 \pm 183.2$ & 0.0332 \\
\hline \multicolumn{4}{|l|}{ HER2 status } \\
\hline Negative & $106(79 \%)$ & $93.3 \pm 133.3$ & \\
\hline Positive & $28(21 \%)$ & $143.9 \pm 162.6$ & 0.0445 \\
\hline
\end{tabular}

$S D$ standard deviation, SBR Scarff-Bloom-Richardson, $P g R$ progesterone receptor 
Fig. $1 F O X P 3, I L-10, T G F \beta 1$, and $C C L 22$ mRNA expression in normal breast and cancer tissues. Clinical samples were subjected to quantitative RT-PCR analysis specific for FOXP3, IL-10, TGF $\beta 1$, and $C C L 22$. Copy numbers of expressed genes are indicated
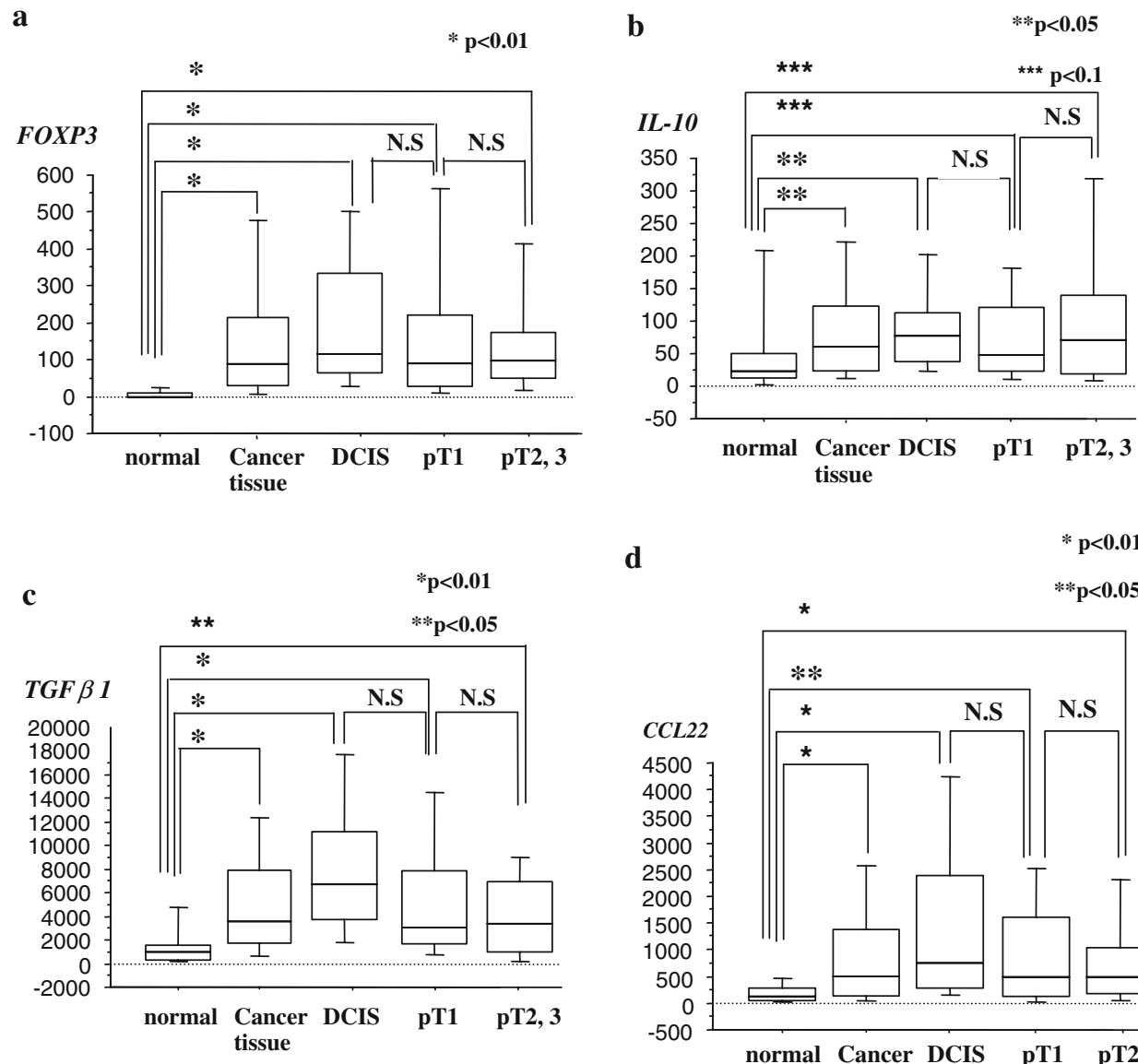

d
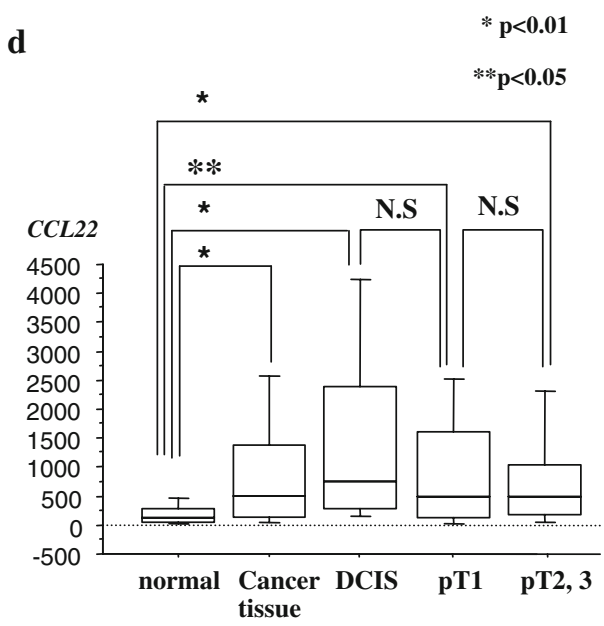

$102.7 \pm 140.1,93.7 \pm 87.8,92.9 \pm 121.4$ and $126.4 \pm 184.5$ copies in $I L-10$ mRNA, for normal breast, total cancer tissue, DCIS, pT1, and pT2, 3 stages, respectively (Fig. 1a, b). FOXP3 and $I L-10$ mRNA expressions showed no correlations with $\mathrm{pN}$ category, tumor histologic type, or lymphatic invasion score (data not shown). However, FOXP3 mRNA expression was positively correlated with tumor grade, and also significantly higher in PgR-negative cancers or HER2-positive cancers (Table 2). Similarly, $I L-10$ mRNA expression was positively correlated with PgR-negative cancers or HER2-positive cancers (Table 2).

\section{TGF $\beta 1$ and CCL22 mRNA expressions}

We also used quantitative RT-PCR to analyze $T G F \beta 1$ and $C C L 22$ mRNA expressions in breast cancer tissue and compared expression levels against each clinicopathological factor. TGF $\beta 1$ and CCL22 mRNA expressions showed no correlation with pT category (data not shown). However, TGF $\beta 1$ and CCL22 mRNA expressions in cancer tissue were significantly upregulated when compared with normal breast tissue $(P<0.01)$, even at the DCIS stage $(P<0.01)$ (Fig. $1 \mathrm{c}, \mathrm{d}) . T G F \beta 1$ and $C C L 22$ mRNA expressions were not correlated with
pN category, a tumor histologic type, tumor grade, lymphatic invasion score, hormone receptor status, or HER2 status, (data not shown).

Correlation between FOXP3 mRNA expression and expressions of $I L-10, T G F \beta 1$, and CCL22 mRNA

The relationships between FOXP3 mRNA expression and expressions of $I L-10, T G F \beta 1$, and CCL22 mRNA were analyzed (Fig. 2a-c). Positive correlations were observed between expressions of FOXP3 and IL-10, FOXP3 and $T G F \beta 1$, and FOXP3 and CCL22 mRNA (Spearman's $\rho=0.640, P<0.0001 ; \rho=0.307, P=0.0004 ; \rho=0.557$, $P<0.0001$, respectively) (Fig. 2a-c).

\section{Discussion}

It has been reported that low level Foxp3 mRNA expression is detectable in breast epithelium and breast cancer cell lines, where Foxp 3 functions as a breast cancer suppressor gene [22], indicating attention to understand the origin of FOXP3expressing cells; those are breast epithelium, breast cancer cells, or Treg cells. However, they demonstrated that 

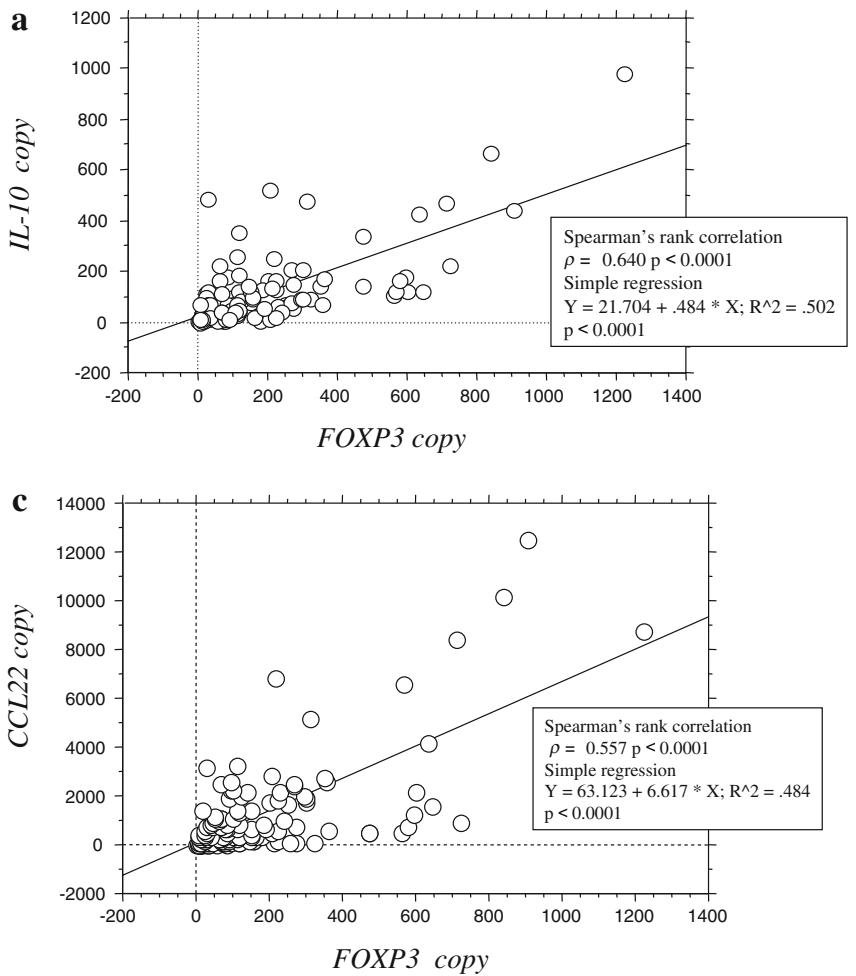

Fig. 2 Regression analysis between $F O X P 3$ mRNA expression and $I L-10, T G F \beta 1, C C L 22$ mRNA expressions. Copy numbers for FOXP3 mRNA were plotted in comparison with copy numbers for $I L-10$ (a),

deletion, functionally significant somatic mutations, and downregulation of the FOXP3 gene were commonly found in human breast cancer samples. In our study, it was observed that FOXP3 expression was higher in tumor tissue than in normal breast tissue. Together, it is strongly suggested that the FOXP3 expression in breast cancer tissue, we observed here, indicates the tumor-infiltrating Treg cell origin.

We hypothesized that Treg cell accumulation in tumor tissue would be augmented in parallel with tumor progression. In this study, higher expression of FOXP 3 mRNA in tumor tissue than in normal breast tissue was observed even at the DCIS stage and persisted at the T1 and T2, 3 stages, indicating that Treg cell accumulation in tumor tissue is an early event in tumor development and progression. Leong et al. [23] have also shown the existence of Treg cells in breast cancer tissue and that there is no significant correlation between tumor stage and $\mathrm{CD} 4+\mathrm{CD} 25+\mathrm{T}$ cells, although they have not mentioned about stage 0 (DCIS). Interestingly, expression of CCL22, which has been shown to be a ligand of CCR4 in Treg cells [20], was also found to be higher in tumor tissue at the DCIS stage than in normal breast tissue in our study. Miller et al. [24] have indicated that Treg cells are an important cellular component of early-stage prostate tumors, and that supernatants from cultured prostate tissue samples and prostate cancer ascites fluid induce migration of Treg cells and contain the chemo-

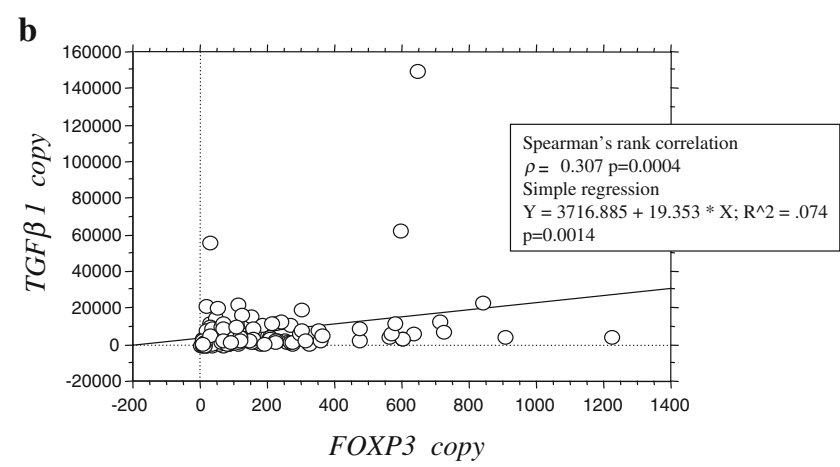

TGF 1 1 (b), and CCL22 (c) mRNA for each patient, and regression analysis was performed to assess the correlations between these values

kine CCL22 as detected by ELISA. It is therefore likely that the homing receptors for Treg cells are induced and expressed in tumor tissues at earlier phases of tumor development, and the subsequent Treg cell accumulation helps tumors to escape from the host immune system, resulting in tumor progression.

Our further analysis showed that FOXP3 mRNA expression was upregulated in PgR-negative and Her2-positive breast cancer tissues and significantly correlated with tumor grade. It has been reported that PgR status significantly improves outcome prediction over ER status alone for adjuvant endocrine therapy of breast cancer patients [25]. HER$2 /$ neu gene amplification and protein overexpression are associated with worsened prognoses in patients with breast cancer [26], even in DCIS tumors [27], suggesting the involvement of FOXP3 expression as a prognostic factor in breast cancer. Bates et al. [11] have investigated the expression of FOXP3 protein in breast cancer by immunohistochemistry and demonstrated that high Treg cell numbers are present in high-grade tumors, in patients with lymph node involvement, and in ER-negative tumors, and HER2positive tumors, consistent with our observations, and that breast cancer patients who express FOXP3 have poorer prognoses. FOXP3-expressing Treg cells can avoid the anti-tumor activity of immune effector cells in breast cancer tissue, resulting in poor prognosis of breast cancer patients. 
It has been shown in some studies that Treg cells may mediate immunosuppression through the secretion of IL-10 [28], and in other studies that TGF $\beta$ or direct cell-to-cell contact may be important for suppression [29]. Gupta et al. [12] have demonstrated that intratumoral FOXP3 mRNA and protein levels were correlated with the levels of TGF $\beta 1$, vascular endothelial growth factor and intratumoral microvessel density. In our study, FOXP3 expression was positively correlated with $I L-10$ and $T G F \beta 1$ expression in breast cancer tissue, and $I L-10$ was much more highly correlated with FOXP3 expression than TGF $\beta 1$. This finding requires careful interpretation. IL-10 has been shown to be secreted by not only Treg cells but also $\mathrm{T}$ helper-type (Th)-2 cells [30]. In addition, it has been demonstrated that tumor cells themselves can produce and secrete IL-10 protein [31], indicating that IL-10 expression in breast cancer tissue does not always require Treg cells. TGF $\beta 1$ is also produced from not only Treg cells, but many cell types including tumor cells, and it is implicated in several aspects of breast cancer onset and progression [32]. However, it has been reported that Treg cells may stimulate Th-2 responses. Suto et al. [33] reported that Treg cells induce Th- 2 cell proliferation in patients with allergic inflammation of the airways. In previous studies of sentinel lymph node immunity in breast cancer, we observed that upregulation of Treg and Th-2 cell responses developed in parallel after metastasis occurred in SNs [8]. Moreover, IL-10-producing Th-2 cells can regulate Th1 effector cell function, resulting in cancer-related imbalance of immune effector cells [31, 32, 34]. Collectively, although the relationship between Treg cells and IL-10 or TGF $\beta 1$ expression should be carefully interpreted, our results may indicate that TGF $\beta 1$ and especially IL-10 are involved in Treg-associated immunosuppression in breast cancer tissues. To our knowledge, this is the first report showing a significant correlation between FOXP3 and IL-10 or TGF $\beta 1$ expression by regression analysis in breast cancer tissue in situ. IL-10 or TGF $\beta 1$ expression in breast cancer tissue in situ should be further assessed in relation to Treg cells, Th2 cells, and tumor cells because of the complexity of the tumor microenvironment. This issue is an interesting question that is being currently addressed in our institute.

Chemotherapeutic agents that attenuate Treg cell function may allow successful chemotherapy for breast cancer, since Treg cells may play a large role in progression of breast cancer. There are several types of combination chemotherapy regimens for breast cancer treatment, and representative protocols often contain an alkylating agent cyclophosphamide [35]. Recent evidence has indicated that cyclophosphamide reduces the number of Treg cells $[36,37]$. The chemotherapeutic activity of cyclophosphamide may be dependent, in part, on the downregulation of Treg cells in vivo. Bates et al. [11] have also pointed out the requirement of targeting Treg cells in breast cancer treatment for preventing late-relapses. More recently, not only chemotherapeutic agents but also molecular targeting agents including anti-CD25 [38], anti-GITR antibodies [39], and IL-2-immunotoxin conjugates [40] have been developed to effectively attenuate Treg cell function. Our results suggest that the success of these clinical investigations for Treg cell attenuation may enhance and improve the efficacy of breast cancer treatment in the future.

Open Access This article is distributed under the terms of the Creative Commons Attribution Noncommercial License which permits any noncommercial use, distribution, and reproduction in any medium, provided the original author(s) and source are credited.

\section{References}

1. Sakaguchi S (2005) Naturally arising Foxp3-expressing CD25+CD4+ regulatory $T$ cells in immunological tolerance to self and non-self. Nat Immunol 6:345-352

2. Yamaguchi T, Sakaguchi S (2006) Regulatory T cells in immune surveillance and treatment of cancer. Semin Cancer Biol 16:115-123

3. Shevach M (2001) Certified professionals: CD4(+)CD25(+) suppressor T cells. J Exp Med 193:F41-F46

4. Liyanage UK, Moore TT, Joo HG, Tanaka Y, Herrmann V, Doherty G, Derbin JA, Strasberg SM, Eberlein TJ, Goedegebuure PS, Linehan DC (2002) Prevalence of regulatory T cells is increased in peripheral blood and tumor microenvironment of patients with pancreas or breast adenocarcinoma. J Immunol 169:2756-2761

5. Liu L, Yao J, Ding Q, Huang S (2006) CD4+CD25 high regulatory cells in peripheral blood of NSCLC patients. J Huazhong Univ Sci Technolog Med Sci 26:548-551

6. Okita R, Saeki T, Takashima S, Yamaguchi Y, Toge T (2005) $\mathrm{CD} 4+\mathrm{CD} 25+$ regulatory $\mathrm{T}$ cells in the peripheral blood of patients with breast cancer and non-small cell lung cancer. Oncol Rep 14:1269-1273

7. Sasada T, Kimura M, Yoshida Y, Kanai M, Takabayashi A (2003) $\mathrm{CD} 4+\mathrm{CD} 25+$ regulatory $\mathrm{T}$ cells in patients with gastrointestinal malignancies: possible involvement of regulatory $\mathrm{T}$ cells in disease progression. Cancer 98:1089-1099

8. Matsuura K, Yamaguchi Y, Ueno H, Osaki A, Arihiro K, Toge T (2006) Maturation of dendritic cells and T-cell responses in sentinel lymph nodes from patients with breast carcinoma. Cancer 106:1227-1236

9. Badoual C, Hans S, Rodriguez J, Peyrard S, Klein C, Agueznay Nel H, Mosseri V, Laccourreye O, Bruneval P, Fridman WH, Brasnu DF, Tartour E (2006) Prognostic value of tumor-infiltrating CD4 + T-cell subpopulations in head and neck cancers. Clin Cancer Res 12:465-472

10. Fox SB, Launchbury R, Bates GJ, Han C, Shaida N, Malone PR, Harris AL, Banham AH (2007) The number of regulatory T cells in prostate cancer is associated with the androgen receptor and hypoxia-inducible factor (HIF)-2 alpha but not HIF-1alpha. Prostate 67:623-629

11. Bates GJ, Fox SB, Han C, Leek RD, Garcia JF, Harris AL, Banham AH (2006) Quantification of regulatory T cells enables the identification of high-risk breast cancer patients and those at risk of late relapse. J Clin Oncol 24:5373-5380

12. Gupta S, Joshi K, Wig JD, Arora SK (2007) Intratumoral FOXP3 expression in infiltrating breast carcinoma: its association with clinicopathologic parameters and angiogenesis. Acta Oncol 46:792-797 
13. Sakaguchi S, Sakaguchi N, Asano M, Itoh M, Toda M (1995) Immunologic self-tolerance maintained by activated $\mathrm{T}$ cells expressing IL-2 receptor alpha-chains (CD25). J Immunol 155:1151-1164

14. Asano M, Toda M, Sakaguchi N, Sakaguchi S (1996) Autoimmune disease as a consequence of developmental abnormality of a T cell subpopulation. J Exp Med 184:387-396

15. Hori S, Nomura T, Sakaguchi S (2003) Contorol of regulatory $\mathrm{T}$ cell development by the transcription factor FoxP3. Science 299:1057-1061

16. Ziegler SF (2006) Foxp3: of mice and men. Annu Rev Immunol 24:209-226

17. Walker MR, Kasprowicz DJ, Gersuk VH, Benard A, Van Landeghen M, Buckner JH, Ziegler SF (2003) Induction of Foxp3 and acquisition of $\mathrm{T}$ regulatory activity by stimulated human CD4+CD25-T cells. J Clin Invest 112:1437-1443

18. Chen W, Jin W, Hardegen N, Lei KJ, Li L, Marions N, McGrady G, Wahl S (2003) Conversion of peripheral CD4+CD25-naïve $\mathrm{T}$ cells to CD4+CD25+ regulatory $\mathrm{T}$ cells by TGF-beta induction of transcription factor Foxp3. J Exp Med 198:1875-1886

19. Nishikawa H, Kato T, Tawara I, Saito K, Ikeda H, Kuribayashi K, Allen PM, Schreiber RD, Sakaguchi S, Old LJ, Shiku H (2005) Definition of target antigens for naturally occurring CD4(+) CD25(+) regulatory T cells. J Exp Med 201:681-686

20. Hirahara K, Liu L, Clark RA, Yamanaka K, Fuhlbrigge RC, Kupper TS (2006) The majority of human peripheral blood CD4+CD25 high Foxp3+ regulatory T cells bear functional skinhoming receptors. J Immunol 177:4488-4494

21. Ueno H, Yoshida K, Hirai T, Kono F, Kambe M, Toge T (2003) Quantitative detection of carcinoembryonic antigen messenger RNA in the peritoneal cavity of gastric cancer patients by real time quantitative reverse transcription polymerase chain reaction. Anticancer Res 23:1701-1708

22. Zuo T, Wang L, Morrison C, Chang X, Zhang H, Li W, Liu Y, Wang Y, Liu X, Chan MW, Liu JQ, Love R, Liu CG, Godfrey V, Shen R, Huang TH, Yang T, Park BK, Wang CY, Zheng P, Liu Y (2007) FOXP3 is an X-linked breast cancer suppressor gene and an important repressor of the HER-2/ErbB2 oncogene. Cell 129:12751286

23. Leong PP, Mohammad R, Ibrahim N, Ithnin H, Abdullah M, Davis WC, Seow HF (2006) Phenotyping of lymphocytes expressing regulatory and effector markers in infiltrating ductal carcinoma of the breast. Immnol Lett 102:229-236

24. Miller AM, Lundberg K, Ozenci V, Banham AH, Hellström M, Egevad L, Pisa P (2006) CD4+CD25 high T cells are enriched in the tumor and peripheral blood of prostate cancer patients. J Immunol 177:7398-7405

25. Bardou VJ, Arpino G, Elledge RM, Osborne CK, Clark GM (2003) PgR status significantly improves outcome prediction over ER status alone for adjuvant endocrine therapy. J Clin Oncol 21:1973-1979

26. Ross JS, Fletcher JA (1998) The HER-2/neu oncogene in breast cancer: prognostic factor, predictive factor, and target for therapy. Oncologist 3:237-252

27. Kepple J, Henry-Tillman RS, Klimberg VS, Layeeque R, Siegel E, Westbrook K, Korourian S (2006) The receptor expression pattern in ductal carcinoma in situ predicts recurrence. Am J Surg 192:6871

28. Asseman C, Mauze S, Leach MW, Coffman RL, Powrie F (1999) An essential role for interleukin 10 in the function of regulatory $T$ cells suppress that inhibit intestinal inflammation. J Exp Med 190:995-1004

29. Chen ML, Pittet MJ, Gorelik L, Flavell RA, Weissleder R, von Boehmer H, Khazaie K (2005) Regulatory T cells suppress tumor specific CD8 Tcell cytotoxicity through TGF- $\beta$ signals in vivo. Proc Natl Acad Sci USA 102:419-424

30. Asselin-Paturel C, Echchakir H, Carayol G, Gay F, Opolon P, Grunenwald D, Chouaib S, Mami-Chouaib F (1998) Quantitative analysis of Th1, Th2 and TGF-beta1 cytokine expression in tumor, TIL and PBL of non-small cell lung cancer patients. Int J Cancer 77:7-12

31. Gastl GA, Abrams JS, Nanus DM, Oosterkamp R, Silver J, Liu F, Chen M, Albino AP, Bander NH (1993) Interleukin-10 production by human carcinoma cell lines and its relationship to interleukin- 6 expression. Int J Cancer 55:96-101

32. Wakefield LM, Piek E, Bottinger EP (2001) TGF-beta signaling in mammary gland development and tumorgenesis. J Mammary Gland Biol Neoplasia 6:67-82

33. Suto A, Nakajima H, Kagami S, Suzuki K, Saito Y, Iwamoto I (2001) Role of CD4(+) CD25(+) regulatory T cells in T helper 2 cell-mediated allergic inflammation in the airways. Am J Respir Crit Care Med 164:680-687

34. Yamaguchi Y, Ohshita A, Kawabuchi Y, Hihara J, Miyahara E, Noma J, Toge T (2004) Locoregional immunotherapy of malignant ascites from gastric cancer using DTH-oriented doses of the streptococcal preparation OK-432: treatment of Th1 dysfunction in the ascites microenvironment. Int J Oncol 24:959-966

35. Goldhirsch A, Glick JH, Gelber RD, Coates AS, Thurlimann B, Senn HJ (2005) Meeting highlights: international expert consensus on the primary therapy of early breast cancer 2005. Ann Oncol $16: 1569-1583$

36. Lutsiak ME, Semnani RT, De Pascalis R, Kashmiri SV, Schlom J, Sabzevari $\mathrm{H}$ (2005) Inhibition of $\mathrm{CD}^{+} 25^{+} \mathrm{T}$ regulatory cell function implicated in enhanced immune response by low-dose cyclophosphamide. Blood 105:2862-2868

37. Ghiringhelli F, Larmonier N, Schmitt E, Parcellier A, Cathelin D, Garrido C, Chauffert B, Solary E, Bonnotte B, Martin F (2004) $\mathrm{CD} 4+\mathrm{CD} 25+$ regulatory $\mathrm{T}$ cells suppress tumor immunity but are sensitive to cyclophosphamide which allows immunotherapy of established tumors to be curative. Eur J Immunol 34:336-344

38. Okawaki M, Yamaguchi Y, Okita R, Ohara M, Okada M (2008) Dose-finding study of anti-CD25 antibody for targeting regulatory $\mathrm{T}$ cells in locoregional immunotherapy of malignant effusion. Hiroshima J Med Sci (in press)

39. Ko K, Yamazaki S, Nakamura K, Nishioka T, Hirota K, Yamaguchi T, Shimizu J, Nomura T, Chiba T, Sakaguchi S (2005) Treatment of advanced tumors with agonistic anti-GITR mAb and its effects on tumor-infiltrating Foxp3+CD25+CD4+ regulatory $\mathrm{T}$ cells. J Exp Med 202:885-891

40. Dannull J, Su Z, Rizzieri D, Yang BK, Coleman D, Yancey D, Zhang A, Dahm P, Chao N, Gilboa E, Vieweg J (2005) Enhancement of vaccine-mediated antitumor immunity in cancer patients after depletion of regulatory T cells. J Clin Invest 115:3623-3633 